\title{
Responses of Communities Affected by the Sinabung Eruption to COVID-19: A Human Rights-Based Review
}

\author{
Reh Bungana Beru Perangin-angin ${ }^{1}$, Fazli Rachman ${ }^{2}$, Prayetno ${ }^{3}$, \\ Muhammad Fahmi Siregar ${ }^{4}$, Majda El Muhtaj ${ }^{5}$ \\ \{rehbungana@unimed.ac.id ${ }^{1}$, fazli.rachman@unimed.ac.id², eno.pray@gmail.com ${ }^{3}$, \\ fahmisrg71@gmail.com ${ }^{4}$, elmuhtaj.73@gmail.com ${ }^{5}$ \} \\ Department of Pancasila and Civic Education, Faculty of Social Sciences, Universitas Negeri Medan \\ Jl. Willem Iskandar Pasar V Medan Estate, Medan City, 20221, Indonesia.
}

\begin{abstract}
The eruption of Mt. Sinabung has been going on for more than a decade. It has devastated homes, schools and agricultural lands. During this disaster, the emergence of COVID-19 has certainly increased to the multi-dimensional problems. This article analyzes the responses of the people of Karo Regency affected by the eruption of Sinabung to adapting the new normal of pandemic. This article is also focuses on the application of human rights-based approach to disaster management within the pandemic. The result indicates the lack of governmental bodies to understand and incorporate human rights-based approach into local policies including all efforts to protect people who are actually affected by the eruption and pandemic COVID-19 as well.
\end{abstract}

Keywords: Human rights, Sinabung, eruption, COVID-19

\section{Introduction}

Mount Sinabung eruption has lasted more than a decade, beginning $27^{\text {th }}$ August 2010 and continues to this day remarkable impact [1]. During the eruption of Sinabung, about twelve thousand people living around Sinabung were evacuated [2]. Thousands of people lost their homes and farmland. Others must evacuate every time Mount Sinabung erupts. Sinabung eruption also destroyed houses, farmland, public facilities, and infrastructure. Even the eruption of Sinabung also claimed lives. Pyroclastic flows caused the deaths of 16 people in Sukameriah Village in 2014 and 9 people in Gamber Village in 2016 [3].

The community and local government of Karo Regency have no experience dealing with eruption disasters because Sinabung inactive since 1600 [4]. This causes various problems to arise when handling the victims of the eruption of Mount Sinabung. Even there has been a conflict between the victims of the eruption and the local government, officials and fellow community members. The problem has not yet completed, Corona Virus Disease 2019 (COVID-19) has emerged in Indonesia in the mid of March 2020 [5], [6]. Dealing with the pandemic, the Karo Regency Government issued some regulations to prevent and increase awareness campaigns to fight COVID-19 [7]. Admittedly, Sinabung eruption and pandemic COVID-19 has hugely devastated multidimensional impacts for the governance of local government and community as well. 
Policies for fighting COVID-19 must be carried out by upholding the applicable legal rules[8]. Therefore, harmonization of policies for handling COVID-19 for the Karo people affected by the eruption of Sinabung needs to be prioritized. The policy should mainstream government efforts to fulfill, protect, and promote human rights [9], [10].

Human rights must be embedded in various government policies. The Declaration on Right to Development positions the right to development as an inalienable fundamental right [11], [12]. Vienna Declaration and Program of Action in 1993 also reaffirmed the position of the individual as the subject of development[13]. Therefore, the people who are affected by the Sinabung eruption must be engaged and encouraged to fully participate in the fulfillment of social guarantee and security policies to anticipate the destructive impacts of COVID-19. Development must be a part of a state effort to guarantee the protection of individual rights to be involved in the fulfilllment of economic, social and cultural rights, and not be a reason to justify the elimination of human rights fulfillment [11], [13]-[15]. Human rights are the key to responding to the COVID-19 pandemic. As the foundational framework to uphold human dignity, human rights enforce to avoid all negative impacts for quality of health to the people's lives and livelihoods including those caused by the pandemic [16].

The multidimensional impact of Sinabung eruption on one side and handling critical mitigated COVID-19 on the other side must be addressed [17]. How the responses of people affected the Sinabung disaster to the pandemic COVID-19 is the key question of this research to be solved. Moreover, this research is aimed to know how human rights incorporated into local governmental policies in dealing with COVID-19 for communities affected by the eruption of Sinabung. Indeed, human rights-based approach in dealing with disasters should be carried out in the protection and fulfillment of human rights to uphold human dignity, especially to vulnerable groups [18]-[20].

\section{Method}

This research used a qualitative approach. Qualitative research was used because it gives researchers the freedom to explore the data in-depth to answer the research problem under study[21]. This research was conducted at Gamber Village, Subdistrict of Simpang Empat, Karo Regency. The data were classified into two resources, primary and secondary. Primary data were collected from the first resources, namely by observation, interview and FGD. Secondary data were collected from official documents, books, journals, research reports and others.

\section{Result and Discussion}

Karo people have felt the impact Sinabung eruption for about 11 years. They lost their homes and farmland. Families who live in the red zone were relocated to various places that tend to be safer. Several community groups living in the red zone were relocated to several different areas and temporary housing was provided for people who were not in the red zone but were affected by the Sinabung eruption. Several village community groups in the red zone were relocated to different areas and provided with temporary shelter.

One of the villages in the red zone and being relocated is Gamber Village. Gamber Village, which is $4 \mathrm{~km}$ from the peak of Sinabung and has been designated as an eruption red 
zone village since 2013 by the Government. After being relocated, the people of Gamber village currently live in four different locations. The Gamber Village Office was moved to the relocation area with the most Gamber villagers to provide optimal service.

Gamber village has been hit by hot clouds since 2016. In addition to losing their homes, about $50 \%$ of agricultural land was damaged because it was covered with pyroclastic material from the Sinabung eruption [22]. The eruption of Mount Sinabung has shaken the resilience of households due to declining incomes. After being relocated, the Gamber people continue to farm, both on their former land and using other people's land in Gamber Village. This is because the funds provided by the government for relocation are not sufficient to purchase adequate land outside Gamber village. In addition, rent for agricultural land in Gamber village is cheaper than in other places that are not in the red zone. Farming is the main skill and livelihood of the Gamber people, therefore they still insist on doing activities and farming in the red zone. They learn to understand the characteristics of the eruption of Sinabung and trying to make friends with Sinabung. They are used to it and are resigned to the fact that their crops will be damaged by the hot clouds and ash from Sinabung.

The COVID-19 pandemic, which has been going on for two years, has had a serious impact on the economic, social and cultural life of the community because it was affected by the eruption of Sinabung. The Gamber community adheres to health regulations and protocols to prevent the spread of COVID-19. The eruption of Sinabung and the COVID-19 pandemic further worsened their living conditions, especially their economic growth. Agricultural products cannot be distributed outside the Karo Regency and can only be sold cheaply around the Karo area. Some even rot because they can't be sold. The eruption and COVID-19, of course, have a vital link with the fulfillment and protection of the human rights of the affected community, social safety net and the economic recovery of the business climate [7], [23]-[25]. Meanwhile, many laws were issued as legal instruments to respond to COVID-19 and its impacts. The policies were an effort by the state to ensure the protection, fulfillment and respect for the human rights of the affected community [13], [14], [26], [27]. Coordination between the central and local governments was carried out to ensure the fulfillment of the rights of the 203 family heads in Gamber village, especially providing the social safety net program to distribute social assistance to the community in various aid schemes.

The social safety net program through a program to distribute social assistance is given evenly to the Gamber village community. Social safety net program in the form of Direct Cash Assistance sourced from the National Government, and Village funds; the Family Hope program; and Recipients of Non-Cash Aid. Meanwhile, other programs such as stunting prevention programs, Supplementary Feeding and Blood Supplementary Tablets for infants, toddlers and pregnant women are still running. These programs seem to reflect the efforts to fulfill community rights, especially in the sphere of economic, social and cultural rights [15].

In addition to the social safety net, the government uses village funds through the Village Cash Intensive Work program innovation. Gamber Village, which has been located in 4 (four) different locations, cannot carry out labour-intensive development [28] because it is temporarily outside the administrative area of Gamber village. Village cash-intensive program intended for poor family members; unemployed; and underemployed as a result of COVID-19 adjustments were made. Based on the aspirations of the residents, the form of Village Cash Intensive Work is adjusted for agricultural needs such as agricultural tools, fertilizers, insecticides and others. The goal is to help and improve the economic resilience of families and villages by utilizing and optimizing all village potentials [28]. Although is not yet optimal, the program benefits are felt by the community as an effort to fulfill the right to welfare and a decent life for community[15]. 
The Gamber Village Government policies for handling COVID-19 and its impacts are policies based on the needs of the Gamber community of eruption victims. One of these policies is the adjustment of the Village Cash Intensive Work program in the form of the agricultural needs of the villagers. Gamber residents are involved in determining village policies for handling COVID-19 and its impacts. The policy of the Gamber Village Government appears to be people-centred by emphasizing the leveraging of community needs based on participation [11]. The human rights-based approach to Gamber policy seems to provide a new way to balance the handling of health emergencies and the broad impact of the COVID-19 pandemic on people's lives and livelihoods including economic, social, cultural, civil and political rights[16], [18].

Indeed, the protection of vulnerable rights groups can be seen through various Gamber Government programs including the fulfillment of children's and women's rights. The Gamber Government's policy is oriented towards participation in encouraging development accountability for handling COVID-19 and its impacts. The development carried out by Gamber Village at least meets the principles of the human rights-based approach to development including participation, accountability and protection of vulnerable groups [11], [18], [19], [29].

The COVID-19 pandemic demonstrates the ability of the state to protect, fulfill and respect the basic rights of affected communities, including civil and political rights [13], [14], [26], [27]. The government's implementation of restrictions on community activities is an effort to ensure the fulfillment of the right to health even though it raises the assumption that it limits freedom [27], [30], [31]. Presumably the effort to limit the spread of COVID-19 is based on the state of emergency by referring to standard human rights principles and national policies as emergency measures for handling COVID-19[31], [32]. Restrictions can be understood to deal with the COVID-19 crisis and ensure the fulfillment of the rights of vulnerable groups exposed to COVID-19 and other communities [31]. Restrictions are also regulated and prescribed in-laws and regulations that guarantee and respect individual and collective rights [9], [31], [33].

\section{Conclusion}

The COVID-19 pandemic has had an impact on the economic, social, and cultural aspects of the Karo people affected by the eruption of Sinabung. Meanwhile, the remarkable efforts to prevent the spread of COVID-19 by the Karo Regency government has complied with a human rights-based approach. The local government has a lack of understanding of the human rights-based approach to development and its significance to fight the pandemic on one side and ensuring the vulnerability of people who are affected the eruption in the other side.

\section{Acknowledgments}

The authors would like to thank Universitas Negeri Medan for providing funding for this research. The authors would like to thank the community and elements of the government of Gamber village, Karo Regency who have been willing to provide the information needed in this study. To the researchers of the Center for Human Rights Studies, Universitas Negeri 
Medan this is an extraordinary collaboration, and we hope this simple article is useful for all communities of scholars.

\section{References}

[1] Karokab.go.id. Erupsi gunung Sinabung terjadi pada tahun 2010, 2013, 2014, 2015, 2016, 2017, 2018, 2019, 2020, 2021. Available from https://www.karokab.go.id/id/covid-19/107gunung-sinabung/status-tanggap-darurat-erupsi-gunung-sinabung/8007-sinabung-dari-tahun-ketahun [Accessed $29^{\text {th }}$ July 2021].

[2] Kusumayudha SB, Lestari P, Paripurno ET. Eruption Characteristic of the Sleeping Volcano, Sinabung, North Sumatera, Indonesia, and SMS Gateway for Disaster Early Warning System. Indones. J. Geogr. 2018; 50(1): 70-77.

[3] Nurwihastuti DW, Astuti AJD, Yuniastuti E, Perangin-Angin RBB, Simanungkalit NM. Volcanic Hazard Analysis of Sinabung Volcano Eruption in Karo North Sumatra Indonesia. Journal of Physics: Conference Series. 2019; 1175(1): 12186.

[4] Nurwihastuti DW, Astuti AJD, Yuniastuti E, Perangin-angin RBB. Pengurangan Risiko Bencana Erupsi Gunung Sinabung. Yogyakarta: Elmatera; 2019.

[5] World Health Organization. WHO Director-General's opening remarks at the media briefing on COVID-19. Available from https://www.who.int/dg/speeches/detail/who-director-general-sopening-remarks-at-the-media-briefing-on-covid-19---20-march-2020 [Accessed $09^{\text {th }}$ April 2020]

[6] Ihsannudin. Fakta Lengkap Kasus Pertama Virus Corona di Indonesia," Available: https://nasional.kompas.com/read/2020/03/03/06314981/fakta-lengkap-kasus-pertama-viruscorona-di-indonesia?page $=$ all [Accessed: $1^{\text {st }}$ Aprtil 2020].

[7] Surat Edaran Bupati Karo Nomor 013 Tahun 2020. Tentang Pencegahan dan Peningkatan Kewaspadaan Terhadap Penyebaran Corona Virus Disease (COVID-19) di Kabupaten Karo.

[8] Jati B and Putra GRA. Optimalisasi Upaya Pemerintah Dalam Mengatasi Pandemi Covid 19 Sebagai Bentuk Pemenuhan Hak Warga Negara. SALAM J. Sos. dan Budaya Syar-i. 2020; 7(5): 473-484.

[9] Undang-Undang Nomor 39 Tahun 1999 Tentang Hak Asasi Manusia.

[10] Leckie S, Gallagher A. Eds., Economic, Social, and Cultural Rights: a Legal Resource Guide: Leckie, Sc. University of Pennsylvania Press; 2011.

[11] Declaration on the Right to Development.

[12] Uvin P. From the Right to Development to the Rights-based Approach: How 'Human rights' Entered Development. Dev. Pract. 2007; 17(4-5): 597-606

[13] Vienna Declaration and Programme of Action.

[14] Universal Declaration of Human Rights.

[15] International Covenant on Economic, Social and Cultural Rights.

[16] United Nations. COVID-19 and Human Rights: We are all in this together. Available: https://www.un.org/sites/un2.un.org/files/un_policy_brief_on_human_rights_and_covid_23_apr il_2020.pdf. [Accessed 23 ${ }^{\text {th }}$ April 2020]

[17] Tempo.co. Mount Sinabung Erupts for First Time During COVID-19 Pandemic. Available from https://en.tempo.co/read/1373966/mount-sinabung-erupts-for-first-time-during-covid-19pandemic. [Accessed $5^{\text {th }}$ Aug 2021].

[18] Joseph S. International Human Rights Law and the Response to the covid-19 Pandemic. J. Int. Humanit. Leg. Stud. 2020; 11(2): 249-269.

[19] Rice K, Felizzi MV, Hagelgans D. Human Rights-Based Approach to Disaster Management: Valparaiso, Chile. J. Hum. Rights Soc. Work. 2017; 2: 117-127.

[20] Njelesani J, Cleave Sr, Tataryn M, Nixo S. Using a Human Rights-Based Approach to Disability in Disaster Management Initiatives. Natural Disasters. S. Cheval, Ed. Rijeka: InTech, 2012: 21-46.

[21] Creswell JW. Educational Research: Planning, Conducting and Evaluating Quantitative and Qualitative Research. Fourth Edi. Boston: Pearson; 2012.

[22] Nurwihastuti DW, Astuti AJD, Yuniastuti E, Perangin-angin RBB. The People Resilience of 
Gamber Village to the Sinabung Eruption in Karo North Sumatra. The 6th Annual Scientific Meeting on Disaster Research 2019 Proceeding Book. 2019; 2: 77-84.

[23] Peraturan Pemerintah Pengganti Undang-Undang Republik Indonesia Nomor 1 Tahun 2020 tentang Kebijakan Keuangan Negara dan Stabilitas Sistem Keuangan Untuk Penanganan Pandemi Corona Virus Disease 2019 (COVID-19) dan/atau dalam Rangka Menghadapi Ancaman yang Membahayakan Perekonomian Nasional dan/atau Stabilitas Sistem Keuangan.

[24] Keputusan Presiden Republik Indonesia Nomor 12 Tahun 2020 Tentang Penetapan Bencana Nonalam Penyebaran Corona Virus Disease 2019 (COVID-19) sebagai Bencana Nasional.

[25] Keputusan Presiden Republik Indonesia Nomor 11 Tahun 2020 tentang Penetapan Kedaruratan Kesehatan Masyarakat Corona Virus Disease 2019 (COVID-19).

[26] Smith RKM et al., Hukum Hak Asasi Manusia. Yogyakarta: Pusat Studi Hak Asasi Manusia Universitas Islam Indonesia; 2008.

[27] Spadaro A. COVID-19: Testing the Limits of Human Rights. Eur. J. Risk Regul. 2020; 11(2): 317-325.

[28] Peraturan Menteri Desa, Pengembangan Daerah Tertinggal, dan Transmigrasi Republik Indonesia Nomor 14 Tahun 2020 tentang Perubahan Ketiga Atas Peraturan Menteri Desa, Pembangunan, Daerah Tertinggal, dan Transmigrasi Nomor 11 Tahun 2019 Tentang Prioritas Penggunaan Dana Desa Tahun; 2020.

[29] Broberg M, Sano HOO. Strengths and Weaknesses in a Human Rights-based Approach to International Development - An Analysis of a Rights-Based Approach to Development Assistance Based on Practical Experiences. Int. J. Hum. Rights. 2018; 22 (5): 664-680.

[30] Amon JJ. COVID-19 and Detention: Respecting Human Rights. Health Hum. Rights. 2020;22(1): 367-370.

[31] Lebret A. COVID-19 Pandemic and Derogation to Human Rights. J. Law Biosci. 2020; 7(1):115.

[32] World Health Organization. Addressing human rights as key to the COVID-19 response. Available:http://familyplanning2020.org/sites/default/files/COVID/WHO-2019-nCoV-SRH-

Rights-2020.1-eng.pdf.[Accesed April 2020].

[33] Undang-Undang Dasar Negara Republik Indonesia Tahun 1945. 